\title{
CHRONIC OBSTRUCTIVE PULMONARY DISEASE AND HEART FAILURE: CLOSER THAN CLOSE
}

\begin{abstract}
Jelena Ostojić ${ }^{1}$ and Hrvoje Pintarić ${ }^{2}$
${ }^{1}$ Special Hospital for Lung Diseases; ${ }^{2}$ Clinical Department of Cardiovascular Medicine, Sestre milosrdnice University Hospital Center, School of Dental Medicine, University of Zagreb, Zagreb, Croatia

SUMMARY - Chronic obstructive pulmonary disease (COPD) and heart failure (HF) both are global epidemics with substantial burden on morbidity and mortality. They present major challenges to healthcare providers and often coexsist. Multiple interactions exist between these conditions. COPD is often responsible for delayed diagnosis of $\mathrm{HF}$ and vice versa, since both conditions have similar symptoms such as dyspnea and poor exercise tolerance based on the skeletal myopathic response rather than the primary organ failure. Patients with COPD also have an increased risk of developing $\mathrm{HF}$ and higher hospitalization and death rates compared with $\mathrm{HF}$ patients without COPD. Echocardiography and pulmonary function tests along with natriuretic peptides should be performed and carefully interpreted. Diagnostic assessment of both conditions present in the same patient is often difficult, but therapeutic approach is also often non-adherent to current guidelines. For example, patients with coexisting COPD and HF receive beta-blockers at disappointingly low rates below 20\%. Closer collaboration between cardiologists and pulmonologists is required for better identification and management of concurrent COPD and HF.
\end{abstract}

Key words: Pulmonary disease, chronic obstructive - diagnosis; Pulmonary disease, chronic obstructive - therapy; Heart failure - diagnosis; Echocardiography; Respiratory function tests

\section{Introduction}

Chronic obstructive pulmonary disease (COPD) is projected to be the fifth leading cause of morbidity and third leading cause of mortality worldwide by $2020^{1}$. Although major advances in the understanding of COPD have been made in recent decades, the heterogeneity of clinical phenotypes, as well as the variability of clinical course continue to be only partially explained. The Global Initiative for Chronic Obstructive Lung Disease (GOLD) was launched in 1997 in order to improve the understanding of the underlying mechanisms of the disease and global awareness of COPD, as well as to reach expert recommendation on the prevention, diagnosis and treatment of COPD. In the first GOLD Workshop Summary Report in 2001,

Correspondence to: Jelena Ostojic, MD, Special Hospital for Lung Diseases, Rockefellerova 3, HR-10000 Zagreb, Croatia

E-mail: jelena.ostojic.zg@gmail.com

Received January 21, 2016, accepted January 16, 2017
COPD is defined as a disease state characterized by airflow limitation that is not fully reversible and is usually progressive. It has also been stated that the disease is associated with an abnormal inflammatory response of the lungs to noxious particles or gases.

The initial COPD ranking system was based on post-bronchodilator spirometry and it has been proven as a useful indicator for treatment, as well as a reliable value to be compared in clinical studies. In other words, in the beginning of our understanding of COPD, the rigidity (and simplicity) of the staging system proved useful. However, it has become evident that the relationship between forced expiratory volume in the first second $\left(\mathrm{FEV}_{1}\right)$ and symptoms is far from perfect and that exacerbations are independently associated with a more rapid function decline and increased mortality risk. Moreover, it seems that high symptom scores may originate not only from airflow limitation, but also from comorbidities. For example, in the ECLIPSE study, a subgroup of patients with 
the highest prevalence of comorbidities also had signs of persistent systemic inflammation ${ }^{2}$.

Consequently, the GOLD Science Committee adopted the novel approach to annual reviews of the ever growing published data with two major revisions of the GOLD document in 2007 and 2011. The GOLD 2011 assessment proposal includes two additional major criteria: the impact of the disease as perceived by the patient and the risk of future exacerbations. Patients are divided into four major categories: less symptoms and low risk (group A), more symptoms and low risk (group B), less symptoms and high risk (group C) and more symptoms and high risk (group D) $)^{3}$.

In clinical practice, the list of variables to be included in comprehensive approach to the individual patient is even longer, including lifestyle characteristics such as persistent smoking or the level of physical activity, biological markers of the disease activity and, very important, additional clinical outcomes such as comorbidities or lung hyperinflation.

\section{COPD and Heart Failure}

Chronic obstructive pulmonary disease is the fourth commonest cause of death worldwide, and the future does not seem bright, as by the year 2020 COPD will be ranked third. COPD and chronic heart failure (CHF) are both global epidemics and have common determinants (smoking and chronic inflammation), which have been shown to play major roles in the pathogenesis of both diseases. Patients with COPD die mainly from non-respiratory diseases: $25 \%$ from cardiovascular diseases, 20\%-33\% from cancer (mainly lung cancer), and $4 \%-35 \%$ from respiratory diseases, mainly respiratory failure during exacerbations ${ }^{4}$.

Among the comorbid conditions associated with CHF, COPD is one that most often delays correct diagnosis of $\mathrm{CHF}$ and is responsible for nonadherence to current treatment guidelines, such as beta blockade. On the other hand, until recently it was often enough that only self-reported COPD was considered sufficient to establish the diagnosis. Still, few reports have addressed this often ignored combination, and fewer still from the pneumonologist's point of view.

\section{Prevalence of Coexisting COPD and CHF}

In most studies, the estimated prevalence of COPD in patients with $\mathrm{CHF}$ ranges from $11 \%$ to $52 \%^{5-12}$. In recent studies, the prevalence is notably higher. The risk ratio of developing heart failure (HF) is 4.5 (95\% confidence interval (95\% CI) 4.25-4.95) in COPD patients after adjustment for cardiovascular risk factors and compared with age-matched controls ${ }^{13}$. In the ECLIPSE study, the overall prevalence of $\mathrm{HF}$ was $7 \%$, but it increased with the severity of airflow limitation ${ }^{14}$.

At least part of the explanation, besides the common risk factors and a rich body of evidence for chronic systemic inflammation and endothelial dysfunction, lies in global aging of the population; almost half of the people aged $\geq 65$ have at least three medical conditions ${ }^{15}$.

All these epidemiological data must be considered with some degree of caution because of the reported significant disparities in using confirmatory diagnostic tests amongst practicing clinicians. Up to one-third of patients labeled with COPD do not fulfill GOLD criteria for the diagnosis. A recent US study showed that among 219 patients discharged from a tertiary centre with both diagnoses of COPD and $\mathrm{HF}, 82 \%$ received echocardiography, as opposed to only $36 \%$ of patients who received pulmonary function testing, which is much less expensive and time consuming than comprehensive echocardiography ${ }^{16}$. In their prospective REPENSAR study, Macchia et al. found that only $6.5 \%$ of cardiologists and $12 \%$ of pulmonologists had certified or ruled out COPD in patients with $\mathrm{CHF}$, or vice vers $a^{17}$. COPD independently predicted failure of the ejection fraction of left ventricle (EFLV) assessment by echocardiography during hospital stay in the Italian TEMISTOCLE study ${ }^{18}$.

Chronic obstructive pulmonary disease strongly predicts hospitalization rate and duration, and non-cardiovascular mortality in $\mathrm{HF}$ patients with 5-year mortality as high as $69 \%$ compared to $58 \%$ in patients without COPD. Also, respiratory infections are associated with cardiac decompensation in $10 \%-16 \%$ of admissions ${ }^{19}$. On the other hand, the prevalence of unrecognized HF in COPD patients presenting to emergency department with acute dyspnea is $20.9 \%$, and unrecognized $\mathrm{HF}$ is a frequent cause of weaning difficulties in COPD patients requiring mechanical ventilation due to severe acute exacerbation of the disease ${ }^{20}$.

\section{Typical Clinical Feature: Dyspnea}

Dyspnea is the most disabling symptom of COPD, which originates from decrease in the capacity of re- 
spiratory muscles to meet an increased mechanical load. Several different mechanisms contribute to this imbalance.

Patients with COPD must generate more negative intrathoracic pressures in order to achieve adequate alveolar ventilation. The pressure output during resting breathing can be more than three times higher comparing with healthy subjects ${ }^{21}$. This means higher oxygen cost of respiration accompanied with less efficiency. Also, inspiratory flow resistance is increased ${ }^{22}$, loss of elastic recoil causes higher relaxation volume, minute ventilation is increased up to $50 \%$ even during resting breathing, and expiratory flow is limited with delayed lung emptying ${ }^{23,24}$.

Hyperinflation decreases the length of the diaphragm and of the rib cage muscles with a significant decrease in the length of the zone of diaphragmatic apposition, so the diaphragmatic contraction is less effective ${ }^{25,26}$. Furthermore, diaphragmatic curvature is also decreased. In the situation when end-expiratory lung volume lies above $70 \%$ of the predicted total lung capacity, inspiratory muscles have to work not only against the elastic recoil of the lungs, but also against elastic recoil of the thoracic cage $\mathrm{e}^{27}$.

About half of the patients with moderate-to-severe COPD have parallel reductions in maximal inspiratory and expiratory muscle strength, possibly due to the generalized muscle weakness ${ }^{27,28}$. The mechanisms contributing to this generalized muscle wasting are malnutrition, altered inflammatory cytokine profile with high plasma levels of tumor necrosis factor alpha (TNF- $\alpha$ ) with activation of the ubiquitin-proteasome proteolytic pathway ${ }^{29-31}$, electrolite and blood gas abnormalities, $\mathrm{HF}^{29}$, weight $\operatorname{loss}^{28}$, and steroid myopathy ${ }^{32}$.

Inspiratory muscle weakness in patients with $\mathrm{CHF}$ is a result of a complex interplay between decreased total number of diaphragmatic actin-myosin crossbridges $^{33}$, reduction in type IIb fibers ${ }^{34}$, decreased regional blood flow, activation of the ubiquitin-proteasome proteolytic pathway by TNF- $\alpha$, decrease in various oxidative enzymes, size and number of mitochon$\mathrm{dria}^{35}$, atrophy of the limb muscle fibers, postcapillary pulmonary hypertension with compensatory vascular remodeling, bronchial congestion, decreased lung compliance and consequently increased work of the diaphragm up to threefold ${ }^{36-37}$ and, to some extent, hyperpnea that could predispose to hyperinflation ${ }^{38,39}$.
Of note, patients with COPD have similar symptom profiles as those with HF, but dyspnea at rest is usually more pronounced.

\section{Diagnostic Pitfalls}

\section{Echocardiography}

Transthoracic echocardiography is often influenced by the poor acoustic windows in patients with emphysema; in a recent study, inadequate visualization caused by air trapping caused unsatisfactory results in $10.4 \%$ of all examined patients with COPD ${ }^{40,41}$. This proportion is even greater in patients with severe and very severe airflow obstruction in emphysema phenotype ${ }^{42}$.

In transesophageal echocardiography, the transducer located behind the heart enables continuous visualization of all four heart chambers without hindrance from lung even during mechanical ventilation. Of note, during transesophageal echocardiography, as well as in interventional cardiology and pulmonology, noninvasive ventilation can reduce the need for deep sedation or general anesthesia and prevent respiratory depression induced by deep sedation ${ }^{43}$.

\section{Cardiac magnetic resonance imaging}

Cardiac magnetic resonance imaging is the accepted reference standard for estimation of left ventricular (LV) volumes and ejection fraction. It is especially recommended in the evaluation of LV function in patients with inadequate visualization on echocardiographic images and could additionally estimate myocardial fibrosis and predict the risk of arrhythmias in COPD patients ${ }^{44}$.

\section{Natriuretic peptides}

Natriuretic peptides are targeted at protecting the cardiovascular system from the effects of volume overload. Both atrial natriuretic peptide (ANP) and B-type natriuretic peptide (BNP) induce vasodilatation, natriuresis and diuresis. BNP is secreted in bursts and has minimal storage, unlike ANP which can be released with minor triggers. In the setting of pressure overload or volume expansion, the synthesis of pre-proBNP in ventricular myocardium is initiated and afterwards the cleavage to proBNP and then to BNP and inactive NTproBNP follows ${ }^{45}$. 
Both BNP and NTproBNP are useful for excluding $\mathrm{HF}$ in subjects presenting with acute or worsening dyspnea. They also provide prognostic information as every $100 \mathrm{pg} / \mathrm{mL}$ increase in BNP level is associated with $35 \%$ increased death risk ${ }^{46}$. Also, BNPs are useful in monitoring the effects of therapeutic interventions and may be used as a tool for screening for subclinical forms of HF. The BNP Consensus Panel Guidelines state that BNP levels lower than $100 \mathrm{pg} / \mathrm{mL}$ have high negative and levels higher than $500 \mathrm{pg} / \mathrm{mL}$ high positive predictive value for HF. Increased levels of both BNP and NTproBNP are associated with female gender, advanced age, acute coronary syndrome without $\mathrm{HF}$, sepsis, acute respiratory distress syndrome (ARDS) and right $\mathrm{HF}^{45}$.

\section{Therapeutic Challenges}

\section{$A C E$ inhibitors or $A R B s$}

Angiotensin-converting enzyme (ACE) inhibitors are the cornerstone of treatment in CHF. Moreover, $\mathrm{ACE}$ inhibition has been demonstrated to prevent smooth muscle atrophy and improve respiratory muscle strength in patients with $\mathrm{HF}^{47}$, and these effects could be especially interesting in patients with concomitant COPD. Also, cross-sectional data from 2431 hypertensive subjects found that lower limb muscle mass was larger in the ACE inhibitor group in a manner proportional to the length of use ${ }^{48}$. However, in a recent small randomized controlled study, Shrikrishna et al. found that fosinopril treatment for 3 months did not alter muscle atrophy signaling or exercise performance in COPD patients with quadriceps weakness ${ }^{49}$.

Andreas et al. evaluated the effects of the angiotensin II receptor blocker irbesartan given over 4 months in 60 patients with COPD and $\mathrm{FEV}_{1}$ of less than $50 \%$ of the predicted value and without obvious cardiovascular disease that would necessitate administration of an ACE inhibitor or angiotensin receptor blocker. In this study, irbesartan did not exert significant effect on the primary end-point maximum inspiratory pressure, but there was a trend towards total lung capacity reduction - a finding that probably deserves prospective investigation ${ }^{50}$.

In conclusion, despite extensive data on the effects of $\mathrm{ACE}$ and angiotensin II type-1 receptor inhibition (ARB) on systemic inflammation and tissue metabo- lism, the body of evidence on the potential effects on pulmonary inflammation, architecture and vasculature or skeletal muscle functional capacity in COPD, especially in the face of reduced oxygen delivery, is still insufficient. Nevertheless, due to the improved outcome of $\mathrm{HF}, \mathrm{ACE}$ inhibitors or ARBs should not be denied in concomitant COPD. In the OPTIMIZE-HF cohort, patients with COPD were less likely to be started on $\mathrm{ACE}-\mathrm{I}$ / $/ \mathrm{ARB}$ s and aldosterone antagonists during hospital stay and were also more likely to have their ACE-Is/ARBs discontinued ${ }^{51}$. It should be emphasized that the regular use of $\mathrm{ACE}$ inhibitors does not induce bronchospasm or increased risk of cough in COPD patients.

\section{Beta blockers}

Beta blockers are still generally underused in $\mathrm{CHF}$ patients, especially those with concomitant COPD. According to the evidence from 12,440 patients in the ESC Heart Failure Long-Term Registry, beta blockers were prescribed to $72 \%$ of hospitalized patients with $\mathrm{HF}$ and $89 \%$ of patients in the outpatient setting, but only $17 \%$ of patients received targeted daily doses ${ }^{52}$. In a recent large sample from primary care in Scotland $(\mathrm{N}=377,439)$, the prevalence of established COPD in patients with $\mathrm{HF}$ was $25 \%$, but only a small minority (18\%) of COPD patients received beta blockers ${ }^{53}$.

Beta-1 blockers (B1B) have 20-fold higher affinity for beta-1 receptors (B1R) than beta-2 receptors $(\mathrm{B} 2 \mathrm{R})$ and, although they tend to lose sensitivity at the high end of dose ranging, patients with COPD are generally free of adverse respiratory effects with unchanged $\mathrm{FEV}_{1}$. Selective B1B do not attenuate B2R agonist-induced bronchodilatatory effects and may actually be beneficial in COPD by enhancing sensitivity to exogenous beta-adrenergic stimulation. Also, recent large observational studies provide some evidence that concomitant long-term use of inhaled antimuscarinic agents or beta agonists along with cardioselective beta blockers actually reduces mortality rates and the risk of exacerbations in patients with $\mathrm{COPD}^{54,55}$. According to a systematic review by Etminan et al. of nine retrospective cohort studies, beta blockers reduce mortality in COPD, most probably due to their cardioprotective effects $^{56}$. However, several types of biases may have affected the cited results and one should note that studies with negative results are much less likely to be published. 
Despite the data collected from meta-analyses, which strongly suggest that selective $\mathrm{B} 1 \mathrm{~B}$ should not be withheld in patients with mild to severe COPD and $\mathrm{HF}$ because their benefits by far outweigh the risks $^{57,58}$, beta blockers are less prescribed before admission (21.1\% vs. 23.8\%, $\mathrm{p}=0.055)$ in COPD patients, and remain underutilized at discharge $(\mathrm{p}<0.001)^{59}$.

Carvedilol is the only non-cardioselective beta blocker approved for treating HF. Since there are no robust data supporting the safety in patients with moderate or severe airways disease, it should be avoided when possible in patients with COPD, especially during acute exacerbations.

In conclusion, cardioselectivity is paramount, and therefore metoprolol, bisoprolol and in particular nebivolol should be the first choice treatment.

\section{Inhaled beta-2 agonists}

For decades, inhaled beta-2 agonists were strongly associated with adverse cardiac effects in COPD patients with pre-existing cardiovascular disease and an increased risk of CHF decompensation (adjusted OR 3.42 ; $95 \%$ CI 1.99 to 5.86 ), also with all-cause mortality in patients with $\mathrm{CHF}^{60}$. Au et al. found direct association between the number of canisters of beta agonist used and the risk of and death from all causes, suggesting caution using beta agonists in patients with left ventricular systolic dysfunction ${ }^{61}$. One might argue that the use of beta agonists, short-acting beta agonists (SABA) in particular, in acute setting merely reflects the degree of dyspnea. In the ACQUIP case-control study, beta agonists in patients with HF were associated with the risk of hospitalization, but adjustment for cardiovascular morbidity, age, beta blocker use, COPD severity and smoking burden made the difference nonsignificant ${ }^{62}$. In short, the poor patient outcomes attributed to beta agonists may actually reflect symptom burden in COPD.

Since long-acting beta agonists (LABA) or/and long-acting antimuscarinic agents (LAMA) are the cornerstone of COPD treatment in all stages for decreasing exacerbation rates, improving lung function and quality of life, prescribing only SABA and/or short-acting muscarinic antagonists (SAMA) for symptom relief and avoiding treating COPD when coexisting with $\mathrm{HF}$ would be as erroneous as denying beta blockers to patients with $\mathrm{HF}$.
There is additional concern of triggering supraventricular and ventricular arrhythmias by LABA, LAMA and their combinations. Multifocal atrial tachycardia (MAT), atrial fibrillation and ventricular arrhythmias often complicate the course of COPD, in particular during acute exacerbations. MAT is often associated with the use of theophylline, pulmonary embolism, hypoxemia, and also other disorders such as hypokalemia or hypomagnesemia, and chronic renal failure ${ }^{63}$. The largest trial of 1429 patients with COPD found that the administration of formoterol or salmeterol, the two most often administered LABAs, did not result in a statistically significant increase in atrial arrhythmias ${ }^{64}$.

One of the most important risk factors of arrhythmias is acute respiratory failure or, in particular, worsening of chronic respiratory failure during acute exacerbations. One of the most important decisions in the acute clinical setting is well-timed noninvasive ventilation.

\section{Conclusion}

Both HF and COPD are global epidemics, especially in the elderly. Both diseases are chronic, progressive, and share many common pathways of low grade systemic inflammation. The prevalence of coexisting $\mathrm{HF}$ and COPD is yet unknown and most certainly underestimated. Understanding both diseases with the use of proper diagnostic tools is mandatory in order to achieve earlier treatment and better long-term prognosis. Concurrent COPD may play part of the missing puzzle in the complex pathophysiology of $\mathrm{HF}$, and vice versa. Considering the high prevalence of ventricular dysfunction in COPD, routine assessment with either BNP or echocardiography should be considered in COPD patients. On the other hand, pulmonary function tests should be performed in all HF patients. Therefore, closer collaboration between pulmonologists and cardiologists should be warranted in the future. Also, there is an urgent need for large prospective randomized trials on long-term effects of different classes of currently recommended drugs including patients with more advanced disease(s), including those with frequent exacerbations, patients with severe impairment of lung function, heavy symptoms, or those with the asthma and COPD overlap syndrome. 


\section{References}

1. Pauwels RA, Buist AS, Calverley PM, Jenkins CR, Hurd SS; GOLD Scientific Committee. Global strategy for the diagnosis, management, and prevention of chronic obstructive pulmonary disease. NHLBI/WHO Global Initiative for Chronic Obstructive Lung Disease (GOLD) Workshop summary. Am J Respir Crit Care Med. 2001;163(5):1256-76.

2. Agusti A, Edwards LD, Celli B, Macnee W, Calverley PM, Müllerova $\mathrm{H}$, et al. Characteristics, stability and outcomes of the 2011 GOLD COPD groups in the ECLIPSE cohort. Eur Respir J. 2013;42(3):636-46, http://dx.doi.org/10.1183/0903 1936.00195212.

3. Vestbo J, Hurd SS, Agustí AG, Jones PW, Vogelmeier C, Anzueto A, et al. Global strategy for the diagnosis, management, and prevention of chronic obstructive pulmonary disease: GOLD executive summary, Am J Respir Crit Care Med. 2013; 187(4):347-65, https://doi.org/10.1164/rccm.201204-0596PP.

4. Fabbri LM, Luppi F, Beghe B. Complex chronic comorbidities of COPD. Eur Respir J. 2008;31:204-12, https://doi.org/ 10.1183/09031936.00114307.

5. Bangdiwala S1, Weiner DH, Bourassa MG. Studies of Left Ventricular Dysfunction (SOLVD) Registry: rationale, design, methods and description of baseline characteristics. Am J Cardiol. 1992;70:347-53.

6. Vaccarino V, Chen YT, Wang Y. Sex differences in the clinical care and outcomes of congestive heart failure in the elderly. Am Heart J. 1999;138:835-42, https://doi.org/ 10.1016/j.ahj.2004. 06.008 .

7. Baker DW, Einstadter D, Thomas C. Mortality trends for 23,505 Medicare patients hospitalized with heart failure in Northeast Ohio, 1991 to 1997. Am Heart J. 2003;146:258-64.

8. Kosibrood M, Lichtman JH, Heidenreich PA. National trends in outcomes among elderly patients with heart failure. Am J Med. 2006;119:616-7.

9. Havranek EP, Masoudi PA, Westfall KA. Spectrum of heart failure in older patients: results from the National Heart Failure project. Am Heart J. 2002;143:412-7.

10. Rathore SS, Foody JM, Wang Y. Sex, quality of care and outcomes of elderly patients hospitalized with heart failure: findings from the National Heart Failure project. Am Heart J. 2005;149:121-8, https://doi.org/ 10.1016/j.ahj.2004.06.008.

11. Milacić N, Milacić B, Milojković M, Ljubisavljević S, Vodopić $\mathrm{S}$, Hasanbegović $\mathrm{M}$, et al. Correlation of $\mathrm{C}$-reactive protein and COPD severity. Acta Clin Croat. 2016;55(1):41-8, https:// doi.org/ 10.20471/acc.2017.56.01.01.

12. Lee DS, Austin PC, Rouleau JL. Predicting mortality among patients hospitalized for heart failure: derivation and validation of a clinical model.J Am Med Assoc. 2003;290:2581-7, https:// doi.org/ 10.1001/jama.290.19.2581.

13. Curkendall SM, DeLuise C, Jones JK. Cardiovascular disease in patients with chronic obstructive lung disease, Saskatchewan Canada cardiovascular disease in COPD patients. Ann Epi- demiol. 2006;16:63-70, https://doi.org/10.1016/j.annepidem. 2005.04.008.

14. Agusti A, Calverley PM, Celli B, Coxson HO, Edwards LD, Lomas DA, et al. Characterisation of COPD heterogeneity in the ECLIPSE cohort. Respir Res. 2010;11:122, https://doi. org/10.1186/1465-9921-11-122.

15. Fabbri LM, Luppi F, Beghe B. Complex chronic comorbidities of COPD. Eur Respir J 2008;31:204-12, https://doi.org/ 10.1183/09031936.00114307.

16. Damarla M, Celli BR. Discrepancy in the use of confirmatory tests in patients hospitalized with the diagnosis of chronic obstructive lung disease or congestive heart failure. Respir Care. 2006;51:1120-4.

17. Macchia A, Rodriguez Moncalvo JJ, Kleinert M, Comignani PD, Gimeno G, Arakaki D, et al. Unrecognised ventricular dysfunction in COPD. Eur Respir J. 2012; 39(1):51-8, https:// doi.org/ 10.1183/09031936.00044411.

18. Di Lenarda A, Scherillo M, Maggioni AP, Acquarone N, Ambrosio GB, Annicchiarico M, et al. Current presentation and management of heart failure in cardiology and internal medicine hospital units: a tale of two worlds - the TEMISTOCLE study. Am Heart J. 2003;146(4):E12, https://doi.org/10.1016/ S0002-8703(03)00315-6.

19. Rusinaru D, Saaidi I, Godard S. Impact of chronic obstructive lung disease on long-term outcome of patients hospitalized for heart failure. Am J Cardiol. 2008;101:353-8, https://doi.org/ 10.1016/j.amjcard.2007.08.046.

20. Nieminen MS, Brutsaert D, Dickstein K, Drexler H, Follath F, Harjola VP, et al. EuroHeart failure survey II (EHFS II): a survey on hospitalized acute heart failure patients: description of population. Eur Heart J. 2006;27:2725-36, https://doi.org/ 10.1093/eurheartj/ehl193.

21. Laghi F, Jubran A, Topeli A, Fahey PJ, Garrity ER Jr, Arcidi $\mathrm{JM}$, et al. Effect of lung volume reduction surgery on neuromechanical coupling of the diaphragm. Am J Respir Crit Care Med. 1998;157:475-83.

22. Officer TM, Pellegrino R, Brusasco V, Rodarte JR. Measurement of pulmonary resistance and dynamic compliance with airway obstruction. J Appl Physiol. 1998;85:1982-8, https:// doi.org/10.1590/S1807-59322009000700008.

23. Tobin MJ, Chadha TS, Jenouri G, Birch SJ, Gazeroglu HB, Sackner MA. Breathing patterns. 1. Normal subjects. Chest. 1983;84:202-5.

24. Tobin MJ, Chadha TS, Jenouri G, Birch SJ, Gazeroglu HB, Sackner MA. Breathing patterns. 2. Diseased subjects. Chest. 1983;84:286-94.

25. Cassart M, Pettiaux N, Gevenois PA, Paiva M, Estenne M. Effect of chronic hyperinflation on diaphragm length and surface area. Am J Respir Crit Care Med. 1997;156:504-8, https:// doi.org/10.1164/ajrccm.156.2.9612089.

26. Laghi F, Harrison MJ, Tobin MJ. Comparison of magnetic and electrical phrenic nerve stimulation in assessment of diaphragmatic contractility. J Appl Physiol. 1996;80:1731-42. 
27. Rochester DF, Braun NM. Determinants of maximal inspiratory pressure in chronic obstructive pulmonary disease. Am Rev Respir Dis. 1985;132:42-7.

28. Decramer M, de Bock V, Dom R. Functional and histologic picture of steroid-induced myopathy in chronic obstructive pulmonary disease. Am J Respir Crit Care Med. 1996;153: 1958-64, https://doi.org/10.1164/ajrccm.153.6.8665061.

29. Hughes PD, Polkey MI, Harrus ML, Coats AJ, Moxham J, Green M. Diaphragm strength in chronic heart failure. Am J Respir Crit Care Med. 1999;160:529-34, https://doi.org/ 10.1164/ajrccm.160.2.9810081.

30. Schols AM, Soeters PB, Mostert R, Pluymers RJ, Wouters EF. Physiologic effects of nutritional support and anabolic steroids in patients with chronic obstructive pulmonary disease: a placebocontrolled randomized trial. Am J Respir Crit Care Med. 1995; 152:1268-74, https://doi.org/10.1371/journal.pone.0084855.

31. Li YP, Reid MB. NF- $\kappa B$ mediates the protein loss induced by TNF- $\alpha$ in differentiated skeletal muscle myotubes. Am J Physiol Regul Integr Comp Physiol. 2000; 279:R1165-70.

32. Decramer M, Lacquet LM, Fagard R, Rogiers P. Corticosteroids contribute to muscle weakness in chronic airflow obstruction. Am J Respir Crit Care Med. 1994;150:11-6, https://doi. org/10.1164/ajrccm.150.1.8025735.

33. Lecarpentier Y, Coirault C, Lerebours G, Desche P, Scalbert E, Lambert $\mathrm{F}$, et al. Effects of angiotensin converting enzyme inhibition on crossbridge properties of diaphragm in cardiomyopathic hamsters of the dilated bio 53-58 strain. Am J Respir Crit Care Med. 1997;155:630-6, https://doi.org/10.1164/ajrccm.155.2.9032205.

34. Sieck GC, Fournier M. Diaphragm motor unit recruitment during ventilatory and nonventilatory behaviors. J Appl Physiol. 1989;66:2539-45.

35. Drexler H, Riede U, Munzel T, König H, Funke E, Just H. Alterations of skeletal muscle in chronic heart failure. Circulation. 1992;85:1751-9.

36. Mancini DM, Henson D, LaManca J, Levine S. Respiratory muscle function and dyspnea in patients with chronic congestive heart failure. Circulation. 1992;86:909-18.

37. Lenique F, Habis M, Lofaso F, Dubois-Randé JL, Harf A, Brochard L. Ventilatory and hemodynamic effects of continuous positive airway pressure in left heart failure. Am J Respir Crit Care Med. 1997;155:500-5, https://doi.org/10.1164/ajrccm.155.2.9032185.

38. O’Donnell DE, D’Arsigny C, Raj S, Abdollah H, Webb KA. Ventilatory assistance improves exercise endurance in stable congestive heart failure. Am J Respir Crit Care Med. 1999; 160:1804-11, https://doi.org/10.1164/ajrccm.160.6.9808134.

39. Duguet A, Tantucci C, Lozinguez O, Isnard R, Thomas D, Zelter M, et al. Expiratory flow limitation as a determinant of orthopnea in acute left heart failure. J Am Coll Cardiol. 2000; 35:690-700.

40. Wheeldon NM, MacDonald TM, Flucker CJ. Echocardiography in chronic heart failure in the community. QJ Med. 1993; 86:17-23.
41. Rutten FH, Moons KG, Cramer MJ. Recognising heart failure in elderly patients with stable chronic obstructive pulmonary disease in primary care: cross sectional study. BMJ. 2005; 331:1379, https://doi.org/10.1136/bmj.38664.661181.55.

42. Vizza CD, Lynch JP, Ochoa LL. Right and left ventricular dysfunction in patients with severe pulmonary disease. Chest. 1998;113:576-83.

43. Ambrosino N, Guarracino F. Unusual applications of noninvasive ventilation. Eur Respir J. 2011;38(2):440-9, https://doi. org/10.1183/09031936.00192810.

44. Assomull RG, Prasad SK, Lyne J, Smith G, Burman ED, Khan $\mathrm{M}$, et al. Cardiovascular magnetic resonance, fibrosis, and prognosis in dilated cardiomyopathy. J Am Coll Cardiol. 2006; 48(10):1977-85, https://doi.org/10.1016/j.jacc.2006.07.049.

45. Daniels LB, Maisel AS. Natriuretic peptides. J Am Coll Cardiol. 2007;50:2357-68.

46. Doust JA, Pietrzak E, Dobson A. How well does B-type natriuretic peptide predict death and cardiac events in patients with heart failure: systematic review. BMJ. 2005;330:625, https:// doi.org/10.1136/bmj.330.7492.625.

47. Coirault C, Hagege A, Chemla D. Angiotensin-converting enzyme inhibitor therapy improves respiratory muscle strength in patients with heart failure. Chest. 2001;119:1755-60.

48. Di Bari M, van de Poll-Franse LV, Onder G, Kritchevsky SB, Newman A, Harris TB, et al. Antihypertensive medications and differences in muscle mass in older persons: the Health, Aging and Body Composition Study. J Am Geriatr Soc. 2004;52(6): 961-6, https://doi.org/10.1111/j.1532-5415.2004.52265.x.

49. Shrikrishna D, Tanner RJ, Lee JY, Natanek A, Lewis A, Murphy $\mathrm{PB}$, et al. A randomized controlled trial of angiotensinconverting enzyme inhibition for skeletal muscle dysfunction in COPD. Chest. 2014;146(4):932-40, https://doi.org/10. 1378/chest.13-2483.

50. Andreas S, Herrmann-Lingen C, Raupach T, Lüthje L, Fabricius JA, Hruska N, et al. Angiotensin II blockers in obstructive pulmonary disease: a randomised controlled trial. Eur Respir J. 2006;27(5):972-9, https://doi.org/10.1183/09031936 .06 .00098105 .

51. O'Connor CM, Abraham WT, Albert NM, Clare R, Gattis Stough W, Gheorghiade M, et al. Predictors of mortality after discharge in patients hospitalized with heart failure: an analysis from the Organized Program to Initiate Lifesaving Treatment in Hospitalized Patients with Heart Failure (OPTIMIZEHF). Am Heart J. 2008;156(4):662-73, https://doi.org/10. 1016/j.ahj.2008.04.030.

52. Maggioni AP, Anker SD, Dahlström U, Filippatos G, Ponikowski P, Zannad F, et al. Are hospitalized or ambulatory patients with heart failure treated in accordance with European Society of Cardiology guidelines? Evidence from 12,440 patients of the ESC Heart Failure Long-Term Registry. Eur J Heart Fail. 2013;15(10):1173-84.

53. Hawkins NM, Jhund PS, Simpson CR, Petrie MC, Macdonald MR, Dunn FG, et al. Primary care burden and treatment of 
patients with heart failure and chronic obstructive pulmonary disease in Scotland. Eur J Heart Fail. 2010;12(1):17-24.

54. Short PM, Lipworth SI, Elder DH, Schembri S, Lipworth BJ. Effect of beta blockers in treatment of chronic obstructive pulmonary disease: a retrospective cohort study. BMJ. 2011;342: d2549.

55. Rutten FH, Zuithoff NP, Hak E, Grobbee DE, Hoes AW. Beta-blockers may reduce mortality and risk of exacerbations in patients with chronic obstructive pulmonary disease. Arch Intern Med. 2010;170(10):880-7, https://doi.org/10.1001/ archinternmed.2010.112.

56. Etminan M, Jafari S, Carleton B, FitzGerald JM. Beta-blocker use and COPD mortality: a systematic review and meta-analysis. BMC Pulm Med. 2012;12:48, https://doi.org/10.1186/ 1471-2466-12-48.

57. Salpeter S, Ormiston T, Salpeter E. Cardioselective beta-blockers for chronic obstructive pulmonary disease. Cochrane Database Syst Rev. 2005;4:CD003566, https://doi.org/10.1002/ 14651858.CD003566.pub2

58. Van der Woude HJ, Zaagsma J, Postma DS. Detrimental effects of beta-blockers in COPD: a concern for nonselective beta-blockers. Chest. 2005;127:818-24.

59. Parissis JT, Andreoli C, Kadoglou N, Ikonomidis I, Farmakis $\mathrm{D}$, Dimopoulou I, et al. Differences in clinical characteristics, management and short-term outcome between acute heart failure patients with chronic obstructive pulmonary disease and those without this co-morbidity. Clin Res Cardiol. 2014; 103(9):733-41, https://doi.org/10.1007/s00392-014-0708-0.

60. Martin RM, Dunn NR, Freemantle SN. Risk of nonfatal cardiac failure and ischemic heart disease with long acting B2Ragonists. Thorax. 1998;53:558-62.

61. Au DH, Udris EM, Fan VS, Curtis JR, McDonell MB, Fihn SD. Risk of mortality and heart failure exacerbations associated with inhaled beta-adrenoceptor agonists among patients with known left ventricular systolic dysfunction. Chest. 2003;123 (6):1964-9.

62. Au DH, Udris EM, Curtis JR, et al. Association between chronic heart failure and inhaled beta-2-adrenoceptor agonists. Am Heart J. 2004;148(5):915-20, https://doi.org/10.1016/j. ahj.2004.03.048.

63. McCord J, Borzak S. Multifocal atrial tachycardia. Chest. 1998;113:203.

64. Hanrahan JP, Grogan DR, Baumgartner RA, et al. Arrhythmias in patients with chronic obstructive pulmonary disease (COPD): occurrence frequency and the effect of treatment with the inhaled long-acting beta2-agonists arformoterol and salmeterol. Medicine (Baltimore). 2008;87(6):319-28.

Sažetak

\section{KRONIČNA OPSTRUKTIVNA PLUĆNA BOLEST I ZATAJENJE SRCA: TAKO BLIZU, A TAKO DALEKO}

\section{J. Ostojić i H. Pintarić}

Kronična opstruktivna plućna bolest (KOPB) i zatajenje srca među vodećim su uzrocima pobolijevanja i smrtnosti u svijetu. Unatoč brojnim poveznicama, kod bolesnika s kroničnom opstruktivnom plućnom bolešću zatajenje srca ostaje često neprepoznato, no vrijedi i obratno. Kod bolesnika s prethodno utvrđenom KOPB dijagnoza zatajenja srca se često postavlja prekasno, no vrijedi i obratno, ponajviše zbog vrlo sličnih simptoma i znakova bolesti poput zaduhe i intolerancije napora uslijed disfunkcije skeletne muskulature. Bolesnici s KOPB-om imaju viši rizik zatajenja srca, ali i češce hospitalizacije i smrtnost od bolesnika sa zatajenjem srca bez pridružene KOPB. Ehokardiografija, testovi plućne funkcije i određivanje natriuretskih peptida trebaju biti neizostavni dio dijagnostičkog postupka i reevaluacije bolesnika uz bližu suradnju subspecijalista kardiologa i pulmologa sa svrhom ne samo pouzdane dijagnoze, već i optimalnog pristupa liječenju bolesnika s često prisutnim komorbiditetima.

Ključne riječi: Plućna bolest, kronična opstruktivna - dijagnostika; Plućna bolest, kronična opstruktiona - terapija; Srčano zatajivanje - dijagnostika; Ehokardiografja; Respiracija, ispitivanje funkcije 